\title{
Clostridium difficile-related postinfectious IBS: a case of enteroglial microbiological stalking and/or the solution of a conundrum?
}

\author{
Gabrio Bassotti ${ }^{1,3}$ (1) $\cdot$ Lara Macchioni $^{2} \cdot$ Lanfranco Corazzi $^{2} \cdot$ Pierfrancesco Marconi $^{2} \cdot$ Katia Fettucciari $^{2}$
}

Received: 31 October 2017 / Revised: 11 December 2017 / Accepted: 20 December 2017 / Published online: 28 December 2017

(c) Springer International Publishing AG, part of Springer Nature 2017

\begin{abstract}
Post-infectious irritable bowel syndrome is a well-defined pathological entity that develops in about one-third of subjects after an acute infection (bacterial, viral) or parasitic infestation. Only recently it has been documented that an high incidence of post-infectious irritable bowel syndrome occurs after Clostridium difficile infection. However, until now it is not known why in some patients recovered from this infection the gastrointestinal disturbances persist for months or years. Based on our in vitro studies on enteric glial cells exposed to the effects of $C$. difficile toxin B, we hypothesize that persistence of symptoms up to the development of irritable bowel syndrome might be due to a disturbance/impairment of the correct functions of the enteroglial intestinal network.
\end{abstract}

Keywords Clostridium difficile $\cdot$ Enteric glial cells $\cdot$ Post-infectious irritable bowel syndrome $\cdot$ Toxin B

\section{Introduction}

It has been estimated that irritable bowel syndrome (IBS) affects up to $18 \%$ of the population worldwide [1]. A defined risk factor for its development is infectious enteritis and it is known as postinfectious-IBS (PI-IBS) [2]. This IBS subtype has been reported following bacterial (Campylobacter jejuni, Salmonella, Shigella spp., Escherichia coli) and viral (norovirus) infections, and parasitic (Giardia duodenalis) infestations [3]. A recent review with meta-analysis carried out on more than 20,000 individuals with infectious enteritis reported than more than $10 \%$ of patients developed IBS later, at a rate four times higher than that found in nonexposed subjects [4].

These recent data did not take into account another enteric pathogen, Clostridium difficile. It is worth noting that asymptomatic colonization with toxigenic strains is

Gabrio Bassotti

gabassot@tin.it

1 Department of Medicine, University of Perugia Medical School, Perugia, Italy

2 Department of Experimental Medicine, University of Perugia Medical School, Perugia, Italy

3 Gastroenterology and Hepatology Section, Santa Maria della Misericordia Hospital, Piazzale Menghini, 1, 06156 San Sisto (Perugia), Italy frequent and up to more than $20 \%$ of patients with a suspected such infection may have alternative etiologies for persistent diarrhea [5, 6]. However, this pathogen, only in the United States, is responsible for half a million infections and it was associated with approximately 29,000 deaths in 2011 [7]. Some sporadic reports obtained from small cohort studies in patients with hospital-acquired infection $[8,9]$ and IBS outpatients [10] yielded conflicting results. Thereafter, a large study in a US military population revealed that more than $14 \%$ of subjects exposed to $C$. difficile later developed functional gastrointestinal disorders (IBS, gastroesophageal reflux disease, dyspepsia, and constipation) compared to $6 \%$ in nonexposed controls. Of interest, the largest rate ratios were seen for IBS among community- (rate ratio $=8.9$ ) and health care-associated (rate ratio $=5.5$ ) $C$. difficile infection [11]. A more recent study on a cohort of more than 300 patients infected with $C$. difficile reported that $25 \%$ of them developed PI-IBS at least 6 months after the infection, a percentage higher than that reported for other pathogens [12]. Interestingly, the analysis of the risk factors evidenced that only a symptoms' duration of more than 7 days was significantly associated with the development of PI-IBS. 


\section{Pathophysiologic aspects}

Several putative pathophysiologic mechanisms, such as altered immune activation, enterochromaffin cells hyperplasia, and impaired barrier function have been reported in PI-IBS [2]. However, information is lacking on a common core of the mechanisms responsible for an impairment of the neuromuscular gut apparatus, and hence of abnormal motility/perception $[3,13]$.

Concerning mechanisms related to specific infectious agents, these have been investigated in a very few cases. For instance, mucosal cellular changes (enterochromaffin cells hyperplasia) [14], abnormal intestinal permeability and cytokine increase [15] have been reported in PI-IBS related to Campylobacter species; abnormalities of immunoendocrine cells [16] have been described in PI-IBS related to Shigella infection; and mucosal cellular changes (enterochromaffin cells decrease and cholecystokinin-containing cell increase) [17] and visceral hypersensitivity [18] have been documented in Giardia infested patients.

Of interest, some of these abnormalities seem to be related to a dysfunction of the enteric glial cells (EGC) [19-21], a key cell population involved in several gastrointestinal conditions, especially those characterized by abnormal motility and inflammation [22-26]. The important role of EGC, besides mechanical/trophic support function [27], involves regulation of gut barrier functions [28], maintenance and modulation of enteric neurotransmission [29], enteric neurons homeostasis [30], and acting as mediators of interactions between the enteric nervous system and the immune system [25, 31]. These functions are particularly interesting in the setting of PI-IBS, in that there are emerging data that immune-mediated barrier defects are found in IBS patients [32, 33]. It is worth noting, however, that EGC, if targets of pathogenic enteric microorganisms, could be the pivotal crossroad from which the most relevant dysfunctions originate and persist.

\section{Interlinks of enteric glial cells with enteric neurons and neurotransmitters}

Enteric glial cells play an active role within the neural circuits that control gut motility [34]. To exert this role, EGC strongly interact with the enteric neurons and neurotransmitters [27, 29]. Most EGC within enteric ganglia are contacted by vesiculated nerve processes with presynaptic specializations [35], and respond to transmitters released by these terminations by expressing a series of receptors for neurotransmitters and neuromodulators [36-39]. Thus, EGC can modulate enteric neural circuits in several ways, such as by supplying neurotransmitters precursors to neurons $[40,41]$, terminating the actions of neurotransmitters from synapses $[42,43]$, and through the generation of neuroactive compounds [44]. In addition, EGC are needed to assure survival of the enteric neurons, as demonstrated by the experimental ablation of the intestinal glial network [45]. Thus, it is conceivable that every damage to the EGC network may in turn reflect on the function of the enteric neurons; on the other hand, since the EGC and the enteric neurons networks are now considered also as a functional entity with reciprocal regulation between its cellular components, especially regarding the intestinal barrier [46], damages to the enteric neurons may influence EGC functions.

\section{PI-IBS after C. difficile infection: a case of a microbiological stalker, or the way to resolve the conundrum?}

The main virulence factors of $C$. difficile are represented by two exotoxins, toxin A (TcdA) and toxin B (TcdB), similar in structure and mechanisms of action [47] (although TcdB is about 1000-fold more potent than TcdA [48]). Both toxins are able to cause adverse effects in enteric cell populations, such as enterocytes, colonocytes, and enteric neurons [47, 49].

A few studies on the effects of $C$. difficile toxins on enteric neurons showed that toxin A stimulates extrinsic sensory nerves and causes uncontrolled gut inflammation, likely mediated by substance $\mathrm{P}$ from primary afferent neurons [50]; this inflammation was prevented by extrinsic surgical denervation $[51,52]$. On the other hand, neuronal activation of VIP-positive pathways after exposure to toxin $\mathrm{B}$ has been hypothesized as an attempt of a protective adaptive response toward a pathogenic agent aggression of the intestinal mucosa [53]. However, to date there is a lack of information on the possible persistence of functional abnormalities in neurons surviving the effects of $C$. difficile toxins.

Recently, we reported that the adverse effects of toxin $\mathrm{B}$ extend to EGC [54]. In fact, TcB in vitro caused in a dose- and time-dependent manner cytopathic and cytotoxic effects on EGC, correlated with Rac1 glucosylation, such as cytoskeleton disorganization, cell-cycle arrest, apoptosis, increased susceptibility to apoptosis induced by proinflammatory cytokines [54]. More importantly, in EGC surviving the cytotoxic effect of TcdB persistently impaired cell functions were observed, such as Rac1 glucosylation and cell-cycle arrest, even though there was evidence of a selfrescuing mechanism as suggested by an increased production of glial-derived neurotrophic factor [54]. Moreover, surviving EGC were more susceptible to TNF $\alpha$ and IFN $\gamma$ 
action, which induces apoptosis to doses of cytokines not affecting control EGC.

By extrapolating these in vitro data to in vivo infection, we could hypothesize three scenarios based on early effects of TcdB on EGC and late consequences of these early effects (Fig. 1): (a) EGC interact with low concentrations of TcdB (Fig. 1a). The early effects are represented by low and transient Rac1 glucosylation and temporary cell-cycle arrest, with none or modest effects on symptoms as late effects; (b) EGC interact with increased concentrations of TcdB which induce moderate apoptosis allowing the survival of a certain percentage of these cells, but with reduced functionality (Fig. 1b). The early effects are represented by persistent Rac1 glucosylation, with an alteration of the molecular pathways downstream to Rac1 such as cell-cycle arrest and cytoskeletal disorganization. The late effects could cause a progressive increase of gastrointestinal symptoms (especially those related to motility/perception) due to a persistent abnormal function and to a slow loss of EGC, partly balanced by a reactive gliogenesis, a mechanism able to counteract pathogenic offences to the gut [55]; (c) EGC interact with high concentrations of TcdB (Fig. 1c). The early effects are represented by a strong apoptosis of EGC, whereas the late effects, with the loss of a consistent number of EGC, might cause disruption of the network of this cell population, resulting in delay of mucosal healing [56] and, if the loss of EGC is massive and overcomes the reactive gliogenesis, most of their function is lost, with devastating effects on other cell populations (e.g., enteric neurons) and persistence of clinical consequences (abnormal motility and visceral perception).

\section{Conclusions}

We hypothesize that $C$. difficile, by means of its toxins, may behave as a microbiological stalker towards the intestinal EGC network and, according to the grade of exposure of these toxins to the gut, disorganize and/or disrupt this network. Since EGC function is of paramount importance for a correct gut homeostasis, the clinical consequences may vary according to the intensity and the duration of the exposure to these toxins. We feel that exposure to amounts of TcdB able to derange EGC function in the time course might explain the persistence of symptoms in patients after $C$. difficile infection, and to indicate a possible way of developing PI-IBS.

However, it must be stressed that our hypothesis is based on in vitro findings, in conditions very simplified compared to in vivo. In fact, the EGC in vitro lack both the complex cellular environment with which interact (neurons, myocytes, immunocytes, etc.) and the soluble factors produced

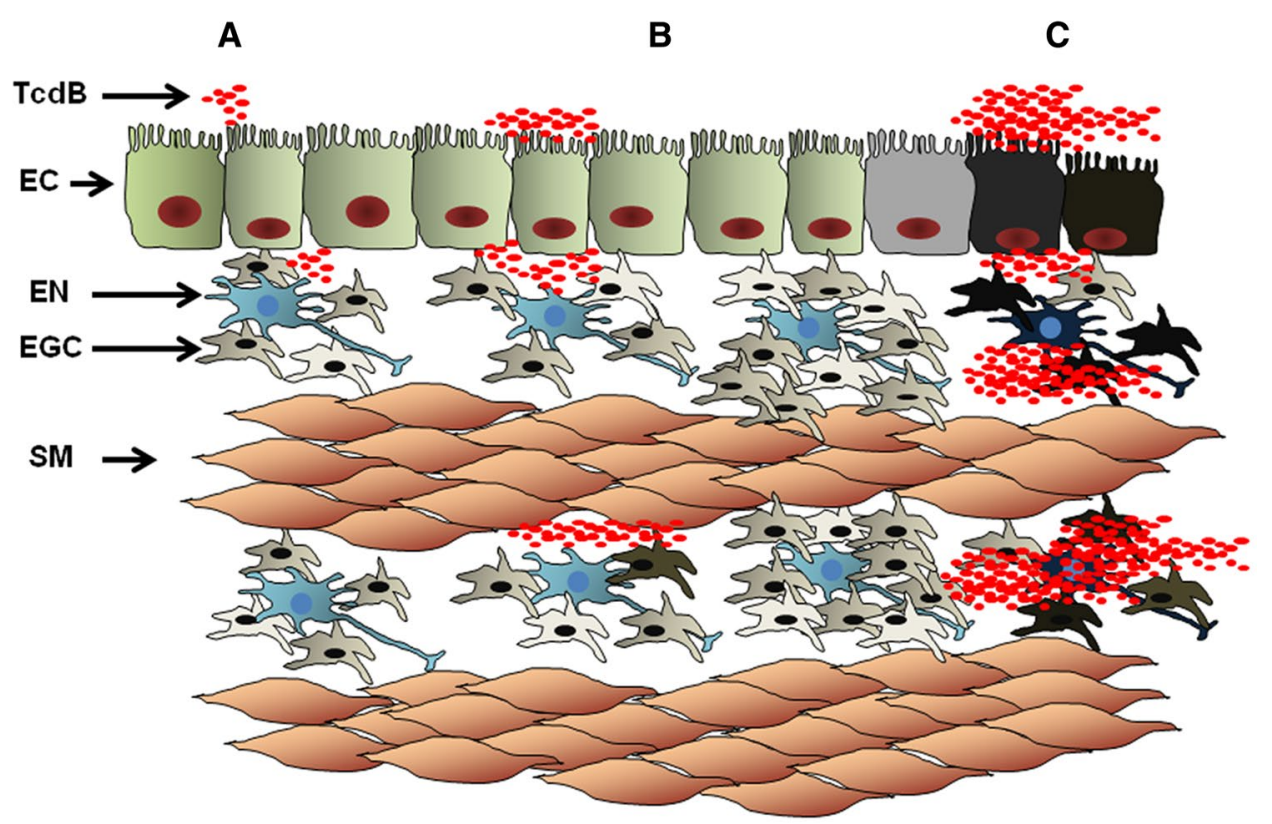

Fig. 1 Hypothesized in vivo effects of TcdB on the enteric glial cell network. a Exposure to low doses of toxin, with transient effects on a few cells (evidenced in lighter colour); $\mathbf{b}$ exposure to increased doses of toxin, which impair EGC function and cause low grades of apoptosis (left, evidenced, respectively, in lighter and darker color), and subsequent reactive gliogenesis with persistent impairment of part of the network (right, lighter color); c exposure to high doses of toxin, with massive apoptosis (dark color) overcoming gliogenesis, loss of the ECG network and of its functions relative to neurons and mucosal healing. EC, epithelial cells; EGC, enteric glial cells; EN, enteric neurons; SM, smooth muscle; TcdB, Clostridium difficile toxin B 
by the interacting cells, such as cytokines and biochemically active metabolites characterizing the inflammatory response evoked by $C$. difficile infection, that in turn evolves in the time course. Thus, further studies are obviously needed to support our observations and hypothesis, and to show whether this approach may be useful to address targeted therapeutic interventions to protect the EGC network.

\section{Compliance with ethical standards}

Conflict of interest The authors declare that they have no competing interests.

\section{References}

1. Chey WD, Kurlander J, Eswaran S (2015) Irritable bowel syndrome: a clinical review. JAMA 313:949-958

2. Spiller R, Garsed K (2009) Postinfectious irritable bowel syndrome. Gastroenterology 136:1979-1988

3. Beatty JK, Bhargava A, Buret AG (2014) Post-infectious irritable bowel syndrome: mechanistic insights into chronic disturbances following enteric infection. World J Gastroenterol 20:3976-3985

4. Klem F, Wadhwa A, Prokop LJ, Sundt WJ, Farrugia G, Camilleri M, Singh S, Grover M (2017) Prevalence, risk factors, and outcomes of irritable bowel syndrome after infectious enteritis: a systematic review and meta-analysis. Gastroenterology 152:1042-1054

5. Zacharioudakis IM, Zervou FN, Pliakos EE, Ziakas PD, Mylonakis E (2015) Colonization with toxinogenic $C$. difficile upon hospital admission, and risk of infection: a systematic review and meta-analysis. Am J Gastroenterol 110:381-390

6. Jackson M, Olefson S, Machan JT, Kelly CR (2016) A high rate of alternative diagnoses in patients referred for presumed Clostridium difficile infection. J Clin Gastroenterol 50:742-746

7. Lessa FC, Mu Y, Bamberg WM, Beldavs ZG, Dumyati GK, Dunn JR, Farley MM, Holzbauer SM, Meek JI, Phipps EC, Wilson LE, Winston LG, Cohen JA, Limbago BM, Fridkin SK, Gerding DN, McDonald LC (2015) Burden of Clostridium difficile infection in the United States. N Engl J Med 372:825-834

8. Sethi S, Garey KW, Arora V, Ghantoji S, Rowan P, Smolensky M, DuPont HL (2011) Increased rate of irritable bowel syndrome and functional gastrointestinal disorders after Clostridium difficile infection. J Hosp Infect 77:172-173

9. Piche T, Vanbiervliet G, Pipau FG, Dainese R, Hébuterne X, Rampal P, Collins SM (2007) Low risk of irritable bowel syndrome after Clostridium difficile infection. Can J Gastroenterol $21: 727-731$

10. Clayton EM, Rea MC, Shanahan F, Quigley EM, Kiely B, Ross RP, Hill C (2012) Carriage of Clostridium difficile in outpatients with irritable bowel syndrome. J Med Microbiol 61:1290-1294

11. Gutiérrez RL, Riddle MS, Porter CK (2015) Increased risk of functional gastrointestinal sequelae after Clostridium difficile infection among active duty United States military personnel (1998-2010). Gastroenterology 149:1408-1414

12. Wadhwa A, Al Nahhas MF, Dierkhising RA, Patel R, Kashyap P, Pardi DS, Khanna S, Grover M (2016) High risk of post-infectious irritable bowel syndrome in patients with Clostridium difficile infection. Aliment Pharmacol Ther 44:576-582

13. Grover M, Camilleri M, Smith K, Linden DR, Farrugia G (2014) On the fiftieth anniversary. Postinfectious irritable bowel syndrome: mechanisms related to pathogens. Neurogastroenterol Motil 26:156-167

14. Spiller RC, Jenkins D, Thornley JP, Hebden JM, Wright T, Skinner M, Neal KR (2000) Increased rectal mucosal enteroendocrine cells, T lymphocytes, and increased gut permeability following acute Campylobacter enteritis and in post-dysenteric irritable bowel syndrome. Gut 47:804-811

15. Swan C, Duroudier NP, Campbell E, Zaitoun A, Hastings M, Dukes GE, Cox J, Kelly FM, Wilde J, Lennon MG, Neal KR, Whorwell PJ, Hall IP, Spiller RC (2013) Identifying and testing candidate genetic polymorphisms in the irritable bowel syndrome (IBS): association with TNFSF15 and TNF $\alpha$. Gut 62:985-994

16. Wang LH, Fang XC, Pan GZ (2004) Bacillary dysentery as a causative factor of irritable bowel syndrome and its pathogenesis. Gut 53:1096-1101

17. Dizdar V, Spiller R, Singh G, Hanevik K, Gilja OH, El-Salhy M, Hausken T (2010) Relative importance of abnormalities of CCK and 5-HT (serotonin) in Giardia-induced post-infectious irritable bowel syndrome and functional dyspepsia. Aliment Pharmacol Ther 31:883-891

18. Dizdar V, Gilja OH, Hausken T (2007) Increased visceral sensitivity in Giardia-induced postinfectious irritable bowel syndrome and functional dyspepsia. Effect of the 5HT3 antagonist ondansetron. Neurogastroenterol Motil 19:977-982

19. Fujikawa $Y$, Tominaga $\mathrm{K}$, Tanaka F, Tanigawa $\mathrm{T}$, Watanabe $\mathrm{T}$, Fujiwara Y, Arakawa T (2016) Enteric glial cells are associated with stress-induced colonic hyper-contraction in maternally separated rats. Neurogastroenterol Motil 27:1010-1023 (Erratum in: Neurogastroenterol Motil 28:306)

20. Wang P, Du C, Chen FX, Li CQ, Yu YB, Han T, Akhtar S, Zuo XL, Tan XD, Li YQ (2016) BDNF contributes to IBS-like colonic hypersensitivity via activating the enteroglia-nerve unit. Sci Rep 6:20320

21. Liñán-Rico A, Turco F, Ochoa-Cortes F, Harzman A, Needleman BJ, Arsenescu R, Abdel-Rasoul M, Fadda P, Grants I, Whitaker E, Cuomo R, Christofi FL (2016) Molecular signaling and dysfunction of the human reactive enteric glial cell phenotype: implications for GI infection, IBD, POI, neurological, motility, and GI disorders. Inflamm Bowel Dis 22:1812-1834

22. Bassotti G, Villanacci V, Antonelli E, Morelli A, Salerni B (2007) Enteric glial cells: new players in gastrointestinal motility? Lab Investig 87:628-632

23. Bassotti G, Villanacci V (2011) Can "functional" constipation be considered as a form of enteric neuro-gliopathy? Glia 59:345-350

24. Sharkey KA (2015) Emerging roles for enteric glia in gastrointestinal disorders. J Clin Investig 125:918-925

25. Chow AK, Gulbransen BD (2017) Potential roles of enteric glia in bridging neuroimmune communication in the gut. Am J Physiol Gastrointest Liver Physiol 312:G145-G152

26. Grubišić V, Verkhratsky A, Zorec R, Parpura V (2017) Enteric glia regulate gut motility in health and disease. Brain Res Bull. https://doi.org/10.1016/j.brainresbull.2017.03.011

27. Grubišić V, Gulbransen BD (2017) Enteric glia: the most alimentary of all glia. J Physiol 595:557-570

28. Savidge TC, Newman P, Pothoulakis C, Ruhl A, Neunlist M, Bourreille A, Hurst R, Sofroniew MV (2007) Enteric glia regulate intestinal barrier function and inflammation via release of $S$-nitrosoglutathione. Gastroenterology 132:1344-1358

29. Gulbransen BD, Sharkey KA (2012) Novel functional roles for enteric glia in the gastrointestinal tract. Nat Rev Gastroenterol Hepatol 9:625-632

30. De Giorgio R, Giancola F, Boschetti E, Abdo H, Lardeux B, Neunlist M (2012) Enteric glia and neuroprotection: basic and clinical aspects. Am J Physiol Gastrointest Liver Physiol 303:G887-G893

31. Margolis KG, Gershon MD (2016) Enteric neuronal regulation of intestinal inflammation. Trends Neurosci 39:614-624 
32. Dunlop SP, Hebden J, Campbell E, Naesdal J, Olbe L, Perkins AC (2006) Spiller RC (2006) Abnormal intestinal permeability in subgroups of diarrhea-predominant irritable bowel syndromes. Am J Gastroenterol 101:1288-1294 (Erratum in: Am J Gastroenterol 101:1944)

33. Lee H, Park JH, Park DI, Kim HJ, Cho YK, Sohn CI, Jeon WK, Kim BI, Chae SW (2013) Mucosal mast cell count is associated with intestinal permeability in patients with diarrhea predominant irritable bowel syndrome. J Neurogastroenterol Motil 19:244-250

34. Broadhead MJ, Bayguinov PO, Okamoto T, Heredia DJ, Smith TK (2012) $\mathrm{Ca}^{2+}$ transients in myenteric glial cells during the colonic migrating motor complex in the isolated murine large intestine. J Physiol 590:335-350

35. Gabella G (1972) Fine structure of the myenteric plexus in the guinea-pig ileum. J Anat 111:69-97

36. Christofi FL, Zhang H, Yu JG, Guzman J, Xue J, Kim M, Wang YZ, Cooke HJ (2001) Differential gene expression of adenosine $\mathrm{A} 1, \mathrm{~A} 2 \mathrm{a}, \mathrm{A} 2 \mathrm{~b}$, and $\mathrm{A} 3$ receptors in the human enteric nervous system. J Comp Neurol 439:46-64

37. Segura BJ, Zhang W, Xiao L, Turner D, Cowles RA, Logsdon C, Mulholland MW (2004) Sphingosine-1-phosphate mediates calcium signaling in guinea pig enteroglial cells. J Surg Res 116:42-54

38. Gulbransen BD, Sharkey KA (2009) Purinergic neuron-toglia signaling in the enteric nervous system. Gastroenterology 136:1349-1358

39. Gulbransen BD, Bains JS, Sharkey KA (2010) Enteric glia are targets of the sympathetic innervation of the myenteric plexus in the guinea pig distal colon. J Neurosci 30:6801-6809

40. Jessen KR, Mirsky R (1983) Astrocyte-like glia in the peripheral nervous system: an immunohistochemical study of enteric glia. J Neurosci 3:2206-2218

41. Nagahama M, Semba R, Tsuzuki M, Aoki E (2001) L-arginine immunoreactive enteric glial cells in the enteric nervous system of rat ileum. Biol Signals Recept 10:336-340

42. Fletcher EL, Clark MJ, Furness JB (2002) Neuronal and glial localization of GABA transporter immunoreactivity in the myenteric plexus. Cell Tissue Res 308:339-346

43. Ruhl A, Hoppe S, Frey I, Daniel H, Schemann M (2005) Functional expression of the peptide transporter PEPT2 in the mammalian enteric nervous system. J Comp Neurol 490:1-11

44. Zhang W, Segura BJ, Lin TR, Hu Y, Mulholland MW (2003) Intercellular calcium waves in cultured enteric glia from neonatal guinea pig. Glia 42:252-262

45. Bush TG, Savidge TC, Freeman TC, Cox HJ, Campbell EA, Mucke L, Johnson MH, Sofroniew MV (1998) Fulminant jejuno-ileitis following ablation of enteric glia in adult transgenic mice. Cell 93:189-201

46. Neunlist M, Van Landeghem L, Mahé MM, Derkinderen P, des Varannes SB, Rolli-Derkinderen M (2013) The digestive neuronal-glial-epithelial unit: a new actor in gut health and disease. Nat Rev Gastroenterol Hepatol 10:90-100

47. Sun X, Savidge T, Feng H (2010) The enterotoxicity of Clostridium difficile toxins. Toxins (Basel) 2:1848-1880

48. Riegler M, Sedivy R, Pothoulakis C, Hamilton G, Zacherl J, Bischof G, Cosentini E, Feil W, Schiessel R, LaMont JT, Wenzl E (1995) Clostridium difficile toxin B is more potent than toxin A in damaging human colonic epithelium in vitro. J Clin Investig 95:2004-2011

49. Pruitt RN, Lacy DB (2012) Toward a structural understanding of Clostridium difficile toxins A and B. Front Cell Infect Microbiol 2:28

50. Anton PM, Gay J, Mykoniatis A, Pan A, O’Brien M, Brown D, Karalis K, Pothoulakis C (2004) Corticotropin-releasing hormone (CRH) requirement in Clostridium difficile toxin A-mediated intestinal inflammation. Proc Natl Acad Sci USA 01:8503-8508

51. Mantyh CR, Pappas TN, Lapp JA, Washington MK, Neville LM, Ghilardi JR, Rogers SD, Mantyh PW, Vigna SR (1996) Substance $\mathrm{P}$ activation of enteric neurons in response to intraluminal Clostridium difficile toxin A in the rat ileum. Gastroenterology 111:1272-1280

52. Mantyh CR, McVey DC, Vigna SR (2000) Extrinsic surgical denervation inhibits Clostridium difficile toxin A-induced enteritis in rats. Neurosci Lett 292:95-98

53. Neunlist M, Barouk J, Michel K, Just I, Oreshkova T, Schemann M, Galmiche JP (2003) Toxin B of Clostridium difficile activates human VIP submucosal neurons, in part via an IL-1betadependent pathway. Am J Physiol Gastrointest Liver Physiol 285:G1049-G1055

54. Fettucciari K, Ponsini P, Gioè D, Macchioni L, Palumbo C, Antonelli E, Coaccioli S, Villanacci V, Corazzi L, Marconi P, Bassotti G (2017) Enteric glial cells are susceptible to Clostridium difficile toxin B. Cell Mol Life Sci 74:1527-1551

55. Joseph NM, He S, Quintana E, Kim YG, Núñez G, Morrison SJ (2011) Enteric glia are multipotent in culture but primarily form glia in the adult rodent gut. J Clin Investig 121:3398-3411

56. Van Landeghem L, Chevalier J, Mahé MM, Wedel T, Urvil P, Derkinderen P, Savidge T, Neunlist M (2011) Enteric glia promote intestinal mucosal healing via activation of focal adhesion kinase and release of proEGF. Am J Physiol Gastrointest Liver Physiol 300:G976-G987 